\section{Evaluation of a Sprayable Formulation of 1-Methylcyclopropene in Floriculture}

\author{
Polyxeni M. Filios ${ }^{1}$ and William B. Miller, \\ Horticulture Section, School of Integrative Plant Science, 134 Plant Science \\ Building, Cornell University, Ithaca, NY 14853 \\ Additional index words. abscission, ethylene, 1-MCP, senescence
}

\begin{abstract}
We conducted a series of studies to determine the efficacy of a sprayable formulation of 1-methylcyclopropene (1-MCP; AFxRD-038) to inhibit ethylenemediated flower abscission in Impatiens walleriana. Exposing Impatiens plants to $1.0 \mu \mathrm{L} \cdot \mathrm{L}^{-1}$ ethylene for 18 hours caused complete abscission of open flowers and most buds. Sprays of the novel 1-MCP formulation at concentrations $>2.5 \mathrm{mg} \cdot \mathrm{L}^{-1}$ protected plants from ethylene. At 5 and $10 \mathrm{mg} \cdot \mathrm{L}^{-1}$, the efficacy of 1-MCP increased as spray volume increased from $102 \mathrm{~mL} \cdot \mathrm{m}^{-2}$ to $306 \mathrm{~mL} \cdot \mathrm{m}^{-2}$. 1-MCP was rainfast with no decrease in efficacy resulting from heavy overhead irrigation within 1-2 minutes of application. Prepared 1-MCP solutions $\left(10 \mathrm{mg} \cdot \mathrm{L}^{-1}\right)$ remained effective up to 2 weeks after mixing if held in airtight containers. The sprayable 1-MCP formulation provided protection against exogenous ethylene for a maximum of 4 days and reduced stress-related abscission from 3 days of darkness (in the absence of exogenous ethylene) at $20{ }^{\circ} \mathrm{C}$ or 40 hours darkness at $28^{\circ} \mathrm{C}$.
\end{abstract}

Postproduction losses are an important financial constraint in the floriculture industry. Loss estimates of 5\% to $30 \%$ per year have been made (Armitage, 1993; Healy, 2009; Jones, 2002; Staby et al., 1978). Losses can occur at many levels from the moment plants leave the production facility until plants are sold to the consumer. Floricultural crops, including many potted plants and bedding plants, are often shipped significant distances in dark trucks that may or may not have adequate temperature control. Losses can be attributed to water stress (especially in the retail environment), damage by mechanical means (vibration, abrasion, breakage) and by ethylene, which may be present exogenously in the shipping chain or could be produced directly by plants and flowers during the stress of transport. In the absence of adequate temperature control, warm temperatures during transport will potentially increase endogenous ethylene production and will increase sensitivity to ethylene whether exogenous or endogenous in nature. In many floriculture crops, ethylene results in flower, bud, or leaf abscission, epinasty, and hastening of senescence (Gibson et al., 2000; Reid and Jiang, 2012).

Skog et al. (2001) measured ethylene levels in midsize to large wholesale and retail businesses in Ontario, Canada. Detectable levels of ethylene $\left(>0.01 \mu \mathrm{L} \cdot \mathrm{L}^{-1}\right)$ were measured in $63 \%$ of air samples and these levels

Received for publication 19 July 2016. Accepted for publication 7 Sept. 2016.

${ }^{1}$ Graduate Student

${ }^{2}$ Professor

${ }^{3}$ Corresponding author. E-mail: wbm8@cornell. edu. ranged from 0.01 to $10 \mu \mathrm{L} \cdot \mathrm{L}^{-1}$. Sources of ethylene included fresh or rotting produce, propane exhaust, smoke, gas-fired heating equipment, leaks from ethylene rooms used for gassing produce, and recently gassed produce. Areas that contained only flowers and had no produce on the premises exhibited ethylene concentrations ranging from undetectable $(<0.01)$ to moderate $\left(1.44 \mu \mathrm{L} \cdot \mathrm{L}^{-1}\right)$. Loading areas should be kept separate from active growing plants and within these confined areas there is a need for ample ventilation, proper maintenance of equipment, and removal of plant debris to reduce ethylene contamination.

As it is unlikely to completely remove nificant effort has been placed into technologies to reduce the effect of ethylene on floriculture crops. 1-MCP binds to ethylene receptor sites on the plant and with proper application will render plants unsusceptible to endogenous and exogenous ethylene for a period depending on plant growth (Blankenship and Dole, 2003). Current use of 1-MCP in floriculture is limited to a gaseous application sold under various names (EthylBloc; Floralife Inc., Walterboro, SC and Ethylene Buster; Chrysal Intl., Naarden, The Netherlands). With this technology, plants are enclosed in a sealed chamber (treatment room or sealed delivery truck) and the gaseous 1-MCP is released from the commercial powder with a wetting agent. The area must remain sealed for a specified time. This treatment method can be limiting to postproduction efficiency and convenience because plants or flowers must be enclosed in the 1-MCP atmosphere from 4 to $10 \mathrm{~h}$ to achieve full protection from ethylene (Jones and Edelman, 2013; Reid and Çelikel, 2008). ethylene from the postproduction chain, a sig-
Other release mechanisms include 1-MCP sachets that are dipped in water and placed into shipping boxes, a technique especially useful for boxed cut flowers or potted plants (Jones and Edelman, 2013).

In the last few years, a sprayable formulation of 1-MCP (AFxRD-038; Rohm and Hass, Philadelphia, PA) has been registered for in-orchard use on fruit (apples, pears, and kiwifruit) and field crops (sunflower, wheat, and rice) as Harvista ${ }^{\mathrm{TM}}$ and Invinsa ${ }^{\mathrm{TM}}$. While the sprayable formulation has gained a significant presence in these crops, it is not currently registered for use on floriculture crops, and information on its use in greenhouse settings is limited.

Impatiens plants are highly sensitive to ethylene and show rapid flower abscission (overnight) when exposed to very low concentrations of ethylene (Dostal et al., 1991). Both Impatiens $\times$ hawkeri (Dostal et al., 1991; Han, 2003) and I. walleriana can benefit from 1-MCP protection to improve postharvest quality (Han, 2003; Skog, 2001). Impatiens, therefore, can serve as an excellent model plant to investigate the use and efficacy of this novel 1-MCP formulation on floral crops.

The objective of this work was to investigate parameters associated with the use of a sprayable formulation of 1-MCP (as AFxRE-038) on Impatiens plants. Concentration, timing of application, spray volume, $\mathrm{pH}$ of spray solution, mixing and storage, overhead irrigation, and duration of protection against exogenous ethylene were investigated.

\section{Materials and Methods}

Plant production. Impatiens walleriana 'Super Elfin Rose Improved' and 'Super Elfin White' (Ball Horticultural Co., West Chicago, IL) and Impatiens hawkeri 'Tamarinda Purple' (Fides Oro, Santa Paula, CA) were grown from seed or vegetative cuttings. Individual plants were transplanted into 10- or 14-cm containers filled with a commercial greenhouse substrate (LM-111; Lambert Peat Moss, Inc., Riviere-Ouelle, Quebec, Canada). Plants were irrigated as needed with $150 \mathrm{mg} \cdot \mathrm{L}^{-1} \mathrm{~N}$ from (Jack's LX ${ }^{\mathrm{TM}}$ 21-5-20; J.R. Peter's Inc., Allentown, PA) and grown in a glass greenhouse at constant air temperature set point of $18{ }^{\circ} \mathrm{C}$ and ambient light. Plants were pinched to encourage branching. Before experimentation, plants were cleaned to remove old or damaged flowers so that only young flowers and unopened buds were present when experiments started.

1-MCP application and ethylene treatment. 1-MCP powder (AFxRD-038, 3.8\% w/w a.i.; AgroFresh, Inc. Springhouse, PA) was gently mixed with reverse osmosis (RO) water until all powder was dissolved and the solution was clear $(\approx 1 \mathrm{~min})$. Unless otherwise indicated, all solutions were prepared with $0.5 \mathrm{~mL} \cdot \mathrm{L}^{-1}$ Capsil (Aquatrols, Paulsboro, NJ). The 1-MCP solution was transferred to a 1-gallon pump sprayer and pressurized within $5 \mathrm{~min}$ of mixing. The solution was sprayed onto plants until runoff 
and allowed to dry for $1 \mathrm{~h}$. Following this, plants were challenged with $1.0 \mu \mathrm{L} \cdot \mathrm{L}^{-1}$ ethylene flowing at $10 \mathrm{~L} \cdot \mathrm{min}^{-1}$ into $0.4-\mathrm{m}^{3}$ plexi-glass boxes fitted with two small $12-\mathrm{V}$ circulation fans. Control plants were in similar boxes with fresh air at the same flow rate. Ethylene streams were prepared with mass flow controllers and a microprocessor (Aalborg Inc., Orangeburg, NY). In some specific experiments (see below), plants were treated with ethylene by enclosure into a $4-\mathrm{m}^{3}$ polyethylene tent and establishing static ethylene concentrations by injection of pure ethylene. In all cases, ethylene treatments were at $20{ }^{\circ} \mathrm{C}$ in darkness for $18 \mathrm{~h}$. Ethylene concentrations were verified by gas chromatography and were maintained within $5 \%$ of desired set point.

Abscission data. Data were recorded on abscised flowers and buds immediately after the plants were removed from ethylene treatment. Data on percentage-abscised flowers were arcsin-transformed analysis of variance (ANOVA) tests were conducted. The TukeyKramer honestly significant difference method was used to conduct pairwise comparisons of all treatments, and ANOVA was performed to test for significance of linear and quadratic fit of 1-MCP treatments (JMP Pro v 10; SAS Institute, Cary, NC).

Expt. 1: Determination of suitable ethylene concentration for flower abscission. Impatiens walleriana 'Super Elfin Rose Improved' plants were treated with $0,0.25,0.75$, and $1 \mu \mathrm{L} \cdot \mathrm{L}^{-1}$ ethylene (flowing) as described above.

Expt. 2: Concentration of sprayable 1-MCP to prevent abscission. Two experiments were conducted. In the first, I. walleriana 'Super Elfin Rose Improved' plants were sprayed with 1-MCP at concentrations of 0 , $0.1,0.5,1$, and $2 \mathrm{mg} \cdot \mathrm{L}^{-1}$. In the second, sprays of $0,2.5,5.0,10$, and $15 \mathrm{mg} \cdot \mathrm{L}^{-1}$ $1-\mathrm{MCP}$ were used. After sprays dried, plants were placed into plexi-glass boxes for treatment with $1 \mu \mathrm{L} \cdot \mathrm{L}^{-1}$ flowing ethylene. Five single-plant replicates were used per treatment. One additional set of plants treated with $0 \mathrm{mg} \cdot \mathrm{L}^{-1} 1-\mathrm{MCP}$ and was kept in the growth chamber at the same temperature and darkness to represent a nonethylene, non-1MCP control.

Expt. 3: Concentration and volume of sprayable 1-MCP to prevent abscission. Impatiens walleriana 'Super Elfin Rose Improved' plants were sprayed with two concentrations of $1-\mathrm{MCP}\left(5\right.$ and $10 \mathrm{mg} \cdot \mathrm{L}^{-1}$ ) and three volumes $(102,204$, and 306 $\mathrm{mL} \cdot \mathrm{m}^{-2}$ ) in a factorial design and allowed to dry before overnight ethylene treatment. Five single-plant replicates were used per treatment. Two additional sets of control plants were not treated with 1-MCP. One set was placed into $1.0 \mu \mathrm{L} \cdot \mathrm{L}^{-1}$ flowing ethylene overnight and the second set was kept in an ethylene-free growth chamber in darkness.

Expt. 4: Water pH and sprayable 1-MCP efficacy. Solutions of $10 \mathrm{mg} \cdot \mathrm{L}^{-1} 1-\mathrm{MCP}$ were mixed using municipal tap water, $\mathrm{RO}$, or Milli-Q (Milli-Q Advantage A10 System; Millipore Corporation, Billerica, MA) water.
The $\mathrm{pH}$ of the source water was $7.87,6.45$, or 5.75 , respectively. Six additional $1-\mathrm{MCP}$ treatments were made with $\mathrm{RO}$ water adjusted to $\mathrm{pH} 4,5,6,7,8$, and 9 . The $\mathrm{pH}$ was adjusted using $1.0 \mathrm{~m} \mathrm{NaOH}$ or $0.1 \mathrm{M} \mathrm{HCl}$. Impatiens walleriana 'Super Elfin Rose Improved' plants were sprayed with 1-MCP solutions and allowed to dry before overnight flowing ethylene treatment. Three singleplant replicates were used per treatment.

The experiment was repeated using $I$. hawkeri 'Tamarinda Purple' with 1-MCP treatments made with $\mathrm{RO}$ water adjusted to

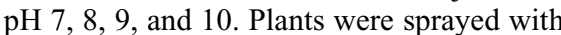
1-MCP solutions and allowed to dry. Plants were then placed into tents for static ethylene treatment $\left(2.5 \mu \mathrm{L} \cdot \mathrm{L}^{-1}\right)$ overnight. Four single-plant replicates were used per treatment.

Expt. 5: Length of 1-MCP effectiveness for prevention of abscission. Individual groups of I. walleriana 'Super Elfin White' plants were sprayed with freshly made 1MCP at $10 \mathrm{mg} \cdot \mathrm{L}^{-1}$ daily, for $6 \mathrm{~d}$, and placed under optimum greenhouse conditions, ultimately leading to plants that had been sprayed with 1-MCP 0-6 d earlier. On day 6 , all plants were treated with $1.0 \mu \mathrm{L} \cdot \mathrm{L}^{-1}$ flowing ethylene overnight.

Expt. 6: Length of time between 1-MCP treatment and overhead irrigation to prevent abscission. Impatiens walleriana 'Super Elfin Rose Improved' plants were sprayed with $10 \mathrm{mg} \cdot \mathrm{L}^{-1} 1-\mathrm{MCP}$ solution. Plants were allowed to stand for $1,2,3,4,5,10$, or $30 \mathrm{~min}$ before each pot was irrigated with $\approx 100 \mathrm{~mL}$ tap water directly overhead through a water breaker (Model 400AL; Dramm Corporation, Manitowoc, WI). Three single-plant replicates were used per treatment. One set of plants was sprayed with 1-MCP and not irrigated. One set of control plants were not treated with 1-MCP or irrigated. After 1-MCP and irrigation treatment, plants were allowed to dry completely and were treated with $1.0 \mu \mathrm{L} \cdot \mathrm{L}^{-1}$ flowing ethylene overnight.

Expt. 7: Duration of overhead irrigation after 1-MCP treatment to prevent abscission. Impatiens walleriana 'Super Elfin Rose Improved' plants were sprayed with $10 \mathrm{mg} \cdot \mathrm{L}^{-1}$ 1-MCP solution. Plants were allowed to dry for 1 or $2 \mathrm{~min}$ before they were irrigated with tap water for 1 or $5 \mathrm{~s}(0.45$ or $2.25 \mathrm{~L}$, respectively) directly overhead using a hose fitted with a water breaker as above. Three single-plant replicates were used per treatment. One set of plants was allowed to dry immediately after 1-MCP treatment without an irrigation treatment. After 1-MCP and irrigation treatment plants were allowed to dry completely and were treated with $1.0 \mu \mathrm{L} \cdot \mathrm{L}^{-1}$ flowing ethylene overnight.

Expt. 8: Efficacy of aged 1-MCP solutions. Solutions of $10 \mathrm{mg} \cdot \mathrm{L}^{-1} 1-\mathrm{MCP}$ were prepared over a period of 7 weeks. Solutions were kept in airtight glass bottles in darkness. Freshly made and 1-, 2-, 4-, 5-, and 7-week-old solutions of 1-MCP were sprayed on I. hawkeri 'Tamarinda Purple' and allowed to dry. Plants were placed in plastic tents for a static $2.5 \mu \mathrm{L} \cdot \mathrm{L}^{-1}$ ethylene treatment overnight. Six single-plant replicates were used per treatment. Two additional sets of plants were treated with $0 \mathrm{mg} \cdot \mathrm{L}^{-1} 1-\mathrm{MCP}$, one set was placed into ethylene overnight and the other kept in an ethylene-free area at the same temperature and darkness.

Expt. 9: 1-MCP to prevent abscission in prolonged darkness. Impatiens hawkeri 'Tamarinda Purple' plants were sprayed with 0 or $10 \mathrm{mg} \cdot \mathrm{L}^{-1} 1-\mathrm{MCP}$ and allowed to dry. Plants were then placed into an ethylene-free dark room at $22{ }^{\circ} \mathrm{C}$ for $1,2,3$, or $4 \mathrm{~d}$. Four or five single-plant replicates were used per treatment.

Expt. 10: 1-MCP to prevent abscission at high temperatures. Impatiens hawkeri 'Tamarinda Purple' plants were sprayed with 0 or $10 \mathrm{mg} \cdot \mathrm{L}^{-1} 1-\mathrm{MCP}$ and allowed to dry. Plants were then placed into plexi-glass boxes with 0 or $1.0 \mu \mathrm{L} \cdot \mathrm{L}^{-1}$ flowing ethylene at $28^{\circ} \mathrm{C}$ for $40 \mathrm{~h}$. Five single-plant replicates were used per treatment.

\section{Results and Discussion}

Expt. 1: Determination of suitable ethylene concentration. Plants showed 50\%, $98 \%$, and $100 \%$ flower abscission after overnight exposure to $0.25,0.75$, and $1 \mu \mathrm{L} \cdot \mathrm{L}^{-1}$, ethylene respectively. This is similar to Dostal et al. (1991) who found that a 6-h treatment with $1 \mu \mathrm{L} \cdot \mathrm{L}^{-1}$ ethylene caused $100 \%$ flower abscission in Impatiens $\times$ hawkeri. Therefore, our further experiments were conducted using $1 \mu \mathrm{L} \cdot \mathrm{L}^{-1}$ exogenous ethylene overnight in darkness. Also, preliminary experiments showed no difference in flower abscission whether plants were enclosed by plastic plant sleeves or loose polyethylene bags (data not shown), thus

Table 1. Flower abscission (\%) of Impatiens walleriana 'Super Elfin Rose Improved' presprayed with varying concentrations of 1-methylcyclopropene (1-MCP; AFxRD-038). After treatment, plants were exposed $1 \mu \mathrm{L} \cdot \mathrm{L}^{-1}$ ethylene or kept in an ethylene-free atmosphere for $18 \mathrm{~h}$ in darkness.

\begin{tabular}{ccc}
\hline $\begin{array}{l}\text { 1-MCP } \\
\text { pretreatment } \\
\left(\mathrm{mg}^{-1} \mathrm{~L}^{-1}\right)\end{array}$ & $\begin{array}{c}\text { Ethylene } \\
\text { treatment } \\
\left(\mu \mathrm{L} \cdot \mathrm{L}^{-1}\right)\end{array}$ & $\begin{array}{c}\text { Flower } \\
\text { abscission }(\%)\end{array}$ \\
\hline $\begin{array}{c}\text { Expt. 1 } \\
0\end{array}$ & 1 & $96^{\mathrm{z}} \mathrm{a}$ \\
0.1 & 1 & $73 \mathrm{~b}$ \\
0.5 & 1 & $47 \mathrm{bc}$ \\
1 & 1 & $43 \mathrm{bc}$ \\
2 & 1 & $25 \mathrm{c}$ \\
Expt. 2 & & \\
0 (control) & 0 & $4 \mathrm{z}^{\mathrm{z}} \mathrm{a}$ \\
0 & 1 & $93 \mathrm{~b}$ \\
2.5 & 1 & $10 \mathrm{a}$ \\
5 & 1 & $10 \mathrm{a}$ \\
10 & 1 & $14 \mathrm{a}$ \\
15 & 1 & $5 \mathrm{a}$ \\
\hline
\end{tabular}

${ }^{\mathrm{z}}$ Data are means of five replicates per treatment For each experiment, letters after values in each column represent means separation using TukeyKramer honestly significant difference at $P=0.05$. Means followed by the same letter are not significantly different. 
Table 2. Flower abscission (\%) of Impatiens walleriana 'Super Elfin Rose Improved' sprayed with varying volumes and concentrations of 1-methylcyclopropene (1-MCP; AFxRD-038). After 1-MCP treatment, plants were exposed $1 \mu \mathrm{L} \cdot \mathrm{L}^{-1}$ ethylene or kept in an ethylene-free atmosphere for $18 \mathrm{~h}$ in darkness.

\begin{tabular}{lccc}
\hline $1-\mathrm{MCP}$ concn $\left(\mathrm{mg} \cdot \mathrm{L}^{-1}\right)$ & Ethylene treatment $\left(\mu \mathrm{L} \cdot \mathrm{L}^{-1}\right)$ & Spray volume $\left(\mathrm{mL} \cdot \mathrm{m}^{-2}\right)$ & Flower abscission $(\%)$ \\
\hline 0 & 0 (control) & 306 & $6^{\mathrm{z}}$ \\
0 & 1 & 306 & 95 \\
5 & 1 & 102 & 34 \\
5 & 1 & 204 & 10 \\
5 & 1 & 306 & 9 \\
10 & 1 & 102 & 17 \\
10 & 1 & 204 & 11 \\
10 & 1 & 306 & 7 \\
$1-\mathrm{MCP}$ concn (M) & & & $\mathrm{NS}$ \\
Spray volume (V) & & & $* *$ \\
M $\times$ V & & & $\mathrm{NS}$ \\
\hline
\end{tabular}

${ }^{\mathrm{z}}$ Data are means of five replicates per treatment.

Ns ${ }^{* *}$ Nonsignificant or significant at $P \leq 0.01$, respectively. Main effects and interaction only refer to the 5 and $10 \mathrm{mg} \cdot \mathrm{L}^{-1} 1-\mathrm{MCP}$ treatments.

Table 3. Flower abscission (\%) of Impatiens walleriana 'Super Elfin Rose Improved' sprayed with $10 \mathrm{mg} \cdot \mathrm{L}^{-1} 1$-methylcyclopropene (1-MCP; AFxRD-038) and exposed to $1 \mu \mathrm{L} \cdot \mathrm{L}^{-1}$ ethylene (for $18 \mathrm{~h}$ in darkness) after 0 to $6 \mathrm{~d}$.

\begin{tabular}{lc}
\hline $\begin{array}{l}\text { Days between 1-MCP spray } \\
\text { and ethylene exposure }\end{array}$ & $\begin{array}{c}\text { Flower } \\
\text { abscission (\%) }\end{array}$ \\
\hline 0 & $4^{\mathrm{z}}$ \\
1 & 8 \\
2 & 12 \\
3 & 15 \\
4 & 28 \\
5 & 54 \\
6 & 65 \\
Significance & $\mathrm{L}^{* * *} \mathrm{Q}^{* *}$ \\
\hline z
\end{tabular}

${ }^{\mathrm{z}}$ Data are means of four replicates per treatment. Significance of linear (L) or quadratic (Q) regression: ${ }^{* *},{ }^{* * *}$ Significant at $P \leq 0.01$ or 0.001 , respectively.

Table 4. Flower abscission (\%) of Impatiens walleriana 'Super Elfin Rose Improved' sprayed with 1-methylcyclopropene (1-MCP; AFxRD-038). After pretreatment, plants were held for 0 to $30 \mathrm{~min}$, then irrigated (overhead) with $100 \mathrm{~mL}$ tap water. After irrigation plants were allowed to dry for $2 \mathrm{~h}$, then exposed to $1 \mu \mathrm{L} \cdot \mathrm{L}^{-1}$ ethylene for $18 \mathrm{~h}$ in darkness.

\begin{tabular}{lcc}
\hline $\begin{array}{l}1-\mathrm{MCP} \\
\text { treatment } \\
\left(\mathrm{mg} \cdot \mathrm{L}^{-1}\right)\end{array}$ & $\begin{array}{c}\text { Time } \\
\text { elapsed before } \\
\text { irrigation (min) }\end{array}$ & $\begin{array}{c}\text { Flower } \\
\text { abscission }(\%)\end{array}$ \\
\hline 0 (control) & $-{ }^{\mathrm{z}}$ & $97^{\mathrm{y}}$ \\
10 & $-{ }^{\mathrm{z}}$ & 3 \\
10 & 1 & 1 \\
10 & 2 & 1 \\
10 & 3 & 4 \\
10 & 4 & 2 \\
10 & 5 & 0 \\
10 & 10 & 3 \\
10 & 30 & 2 \\
Significance & & $\mathrm{NS}$ \\
\hline
\end{tabular}

${ }^{\mathrm{z}}$ Plants were not irrigated after 1-MCP treatments. ${ }^{\mathrm{y}}$ Data are means of three replicates per treatment. ${ }^{\mathrm{N} N}$ Nonsignificant refers only to plants treated with 1-MCP.

these were routinely used to isolate abscised flowers to each plant.

Expt. 2: Concentration of sprayable 1MCP to prevent abscission. Sprays of 1-MCP at concentrations from 0.1 to $2.0 \mathrm{mg} \cdot \mathrm{L}^{-1}$ significantly reduced ethylene-induced
Table 5. Flower abscission (\%) of Impatiens walleriana 'Super Elfin Rose Improved' sprayed $10 \mathrm{mg} \cdot \mathrm{L}^{-1} \quad$ 1-methylcyclopropene (1-MCP; AFxRD-038). After treatment, plants were held for 1 or $2 \mathrm{~min}$ and then irrigated overhead with 0.45 or $2.25 \mathrm{~L}$ tap water. After irrigation, plants were allowed to dry for $2 \mathrm{~h}$ and then exposed to $1 \mu \mathrm{L} \cdot \mathrm{L}^{-1}$ ethylene for $18 \mathrm{~h}$ in darkness.

Time

elapsed before Volume of $\quad$ Flower

irrigation (min) irrigation (L) abscission (\%)

$\begin{array}{lll}\mathrm{N} / \mathrm{A}^{\mathrm{z}} & \overline{\mathrm{z}}^{\mathrm{z}} & 8^{\mathrm{y}}\end{array}$

$\begin{array}{lll}1 & 0.45 & 5 \\ 1 & 2.25 & 4 \\ 2 & 0.45 & 4 \\ 2 & 2.25 & 7\end{array}$

Significance

Time (T)

Volume (V)

NS

$\mathrm{T} \times \mathrm{V}$

NS

${ }^{\mathrm{z}}$ Plants were not irrigated after 1-MCP treatment.

${ }^{\mathrm{y}}$ Data are means of three replicates per treatment.

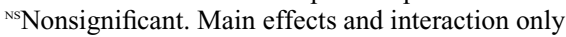
refer to plants irrigated after 1-MCP treatment.

flower abscission (Table 1). There was a significant difference between plants treated with 2.0 and $0.1 \mathrm{mg} \cdot \mathrm{L}^{-1} 1-\mathrm{MCP}$. The linear and quadratic regressions of 1-MCP concentration and flower abscission were highly significant at $P \leq 0.001$ and 0.01 , respectively. However, the $25 \%$ abscission seen with $2.0 \mathrm{mg} \cdot \mathrm{L}^{-1} 1-\mathrm{MCP}$ would still render plants unmarketable. In a second experiment, there was no difference in flower abscission when 1-MCP was sprayed at rates of 2.5$15 \mathrm{mg} \cdot \mathrm{L}^{-1}$ (Table 1). These results suggest that $2.5 \mathrm{mg} \cdot \mathrm{L}^{-1} 1-\mathrm{MCP}$ spray concentration is the lowest concentration for protection against an overnight exposure to $1.0 \mu \mathrm{l} \cdot \mathrm{L}^{-1}$ ethylene.

Expt. 3: Concentration and volume of sprayable 1-MCP to prevent abscission. In this experiment, only 1-MCP spray volume was significant $(P=0.004), 1-\mathrm{MCP}$ concentration and the concentration $\times$ volume interaction were not significant $(P=0.1983$ and 0.0829 , respectively) (Table 2 ). Within $1-\mathrm{MCP}$ concentrations, the percentage of flowers that abscised decreased as the spray volume increased. MacKinnon et al. (2009) saw similar results in tomato with higher spray volume leading to higher efficacy of
$1-\mathrm{MCP}$ in preventing epinasty after ethylene exposure. This is likely due to better coverage of plants from the greater spray volumes. It was suggested that 1-MCP in the aqueous form may have limited translocation in tomatoes (MacKinnon et al., 2009) and as seen with Impatiens, it appears important to fully cover all foliage and flowers with spray solution to achieve 1-MCP binding to open ethylene receptor sites.

Studies of aqueous 1-MCP on plums (Manganaris et al., 2007), tomatoes, and avocadoes (Choi et al., 2008) suggest that complete coverage of target plant material is necessary to achieve full protection from ethylene-mediated senescence. When tomatoes and avocadoes were partially immersed in an aqueous 1-MCP solution, there was uneven protection of the fruit showing limited diffusive capacity of aqueous 1-MCP on the surface of treated plants (Choi et al., 2008).

Volumes of $204 \mathrm{~mL} \cdot \mathrm{m}^{-2}$ (equal to $2 \mathrm{qts} /$ $100 \mathrm{ft}^{2}$ ) are generally recommended for plant growth regulator applications (Latimer and Whipker, 2012) and this experiment confirmed that current greenhouse industry spray protocols should provide sufficient coverage of 1-MCP when used at rates of 5 and $10 \mathrm{mg} \cdot \mathrm{L}^{-1}$

Expt. 4: Water quality and sprayable $1-M C P$ efficacy. There was no difference in $1-\mathrm{MCP}$ efficacy when prepared with municipal, RO, or Milli-Q water; abscission averaged $8 \%$ across all treatments (data not shown). As $\mathrm{pH}$ of the spray solution increased from 4 to 9 (in RO water), abscission increased from $4 \%$ to $14 \%$. In the second experiment, there was no difference in abscission as $\mathrm{pH}$ increased from 7 to 10 (average of $11 \%$ ). Although $\mathrm{pH} 4$ and 9 were statistically different in the first experiment, we concluded that within the $\mathrm{pH}$ range studied, there is no commercially significant effect of water source $\mathrm{pH}$ on activity of this formulation.

Expt. 5: Length of 1-MCP effectiveness for prevention of abscission. Impatiens walleriana 'Super Elfin White' plants challenged with ethylene within 0 to $3 \mathrm{~d}$ of $1-\mathrm{MCP}$ treatment exhibited significantly less flower abscission than plants challenged with ethylene four or more days after 1-MCP treatment (Table 3). Plants with four or more days delay between 1-MCP treatment and ethylene challenge showed more than $25 \%$ flower abscission and plants were unmarketable. Linear and quadratic regressions were significant at $P<0.001$ and 0.01 , respectively; flower abscission was affected by length of delay between 1-MCP treatment and ethylene challenge. Pelargonium peltatum pretreated with $1.0 \mu \mathrm{L} \cdot \mathrm{L}^{-1}$ gaseous $1-\mathrm{MCP}$ for $2 \mathrm{~h}$ completely inhibited ethylene-induced petal abscission; however, the half-life of 1-MCP activity was $\approx 2,3$, and $6 \mathrm{~d}$ after 1 -MCP treatment at 25 , 20.7 , and $12{ }^{\circ} \mathrm{C}$, respectively, with no residual effect of 1-MCP protection after 4 or $5 \mathrm{~d}$ at 25 or $20.7{ }^{\circ} \mathrm{C}$, respectively (Cameron and Reid, 2001). These results suggest that it is necessary to apply the sprayable formulation of 1-MCP a maximum of $3 \mathrm{~d}$ before 
plants will be exposed to exogenous ethylene. The likely reason for this transient effect is due to creation of new ethylene receptors in the actively growing plant, which are not protected by the previous 1-MCP treatment (Blankenship and Dole, 2003; Cameron and Reid, 2001).

Expt. 6: Length of time between 1-MCP treatment and overhead irrigation. There was no significant difference in flower abscission between plants treated with 1-MCP only and those receiving irrigation 1 to 30 min after 1-MCP treatment (Table 4). The linear and quadratic regressions were not significant. All 1-MCP and irrigation treatments protected plants from external ethylene at a market acceptable level showing that complete 1-MCP protection is conferred within one minute of 1-MCP application. MacKinnon et al. (2009) challenged tomatoes with irrigation 15 to $240 \mathrm{~min}$ after 1-MCP pretreatment and found that there was no significant difference from untreated controls suggesting that $1-\mathrm{MCP}$ is rainfast on tomatoes as early as 15 min after application. This would allow practitioners the opportunity to apply sprayable 1-MCP without concern that future rain or irrigation will negatively affect the application.

Expt. 7: Duration of overhead irrigation after 1-MCP treatment to prevent abscission. There was no significant difference between I. walleriana 'Super Elfin Rose Improved' plants treated with 1-MCP solutions only and those receiving an overhead irrigation treatment 1 or 2 min after the 1-MCP spray. The time between 1-MCP application and irrigation, irrigation volume, and the interaction of time $\times$ volume were all nonsignificant (Table 5). The U.S. Label for AFxRD-038 suggests that 1-MCP sprays should be applied under drying conditions, in early morning or at night to allow for adequate absorption, irrigation should not be used for at least $2 \mathrm{~h}$ following application and spray should be use $1 \mathrm{~h}$ before expected rain (EPA, 2010). These results, with the results of Expt. 5 , show that irrigation or rainfall $1 \mathrm{~min}$ after 1-MCP treatment, regardless of irrigation volume, will not reduce 1-MCP efficacy in Impatiens plants.

Expt. 8: Efficacy of aged 1-MCP solutions. Solutions of 1-MCP lost effectiveness as the age of the solution increased beyond 2 weeks and effectiveness was especially lost as solutions aged from 2 to 4 weeks (Table 6). This finding is at odds with recommendations that AFxRD-038 be used very soon after mixing (EPA, 2010) in that efficacy was maintained for at least $14 \mathrm{~d}$ after mixing. One explanation for this is that the concentration of the prepared solution, $10 \mathrm{mg} \cdot \mathrm{L}^{-1}$, was 4 -fold greater than the minimum effective concentration of $2.5 \mathrm{mg} \cdot \mathrm{L}^{-1}$. We surmise that the solution was releasing gaseous 1-MCP more or less continually after mixing, and between weeks 2 and 4 enough had been lost to cause a failure in protection from ethylene. If this is true, mixing protocols could be extremely important in experiments and applications where the

Table 6. Flower abscission (\%) of Impatiens hawkeri 'Tamarina Purple' pre-treated with $10 \mathrm{mg} \cdot \mathrm{L}^{-1}$ 1-methylcyclopropene (1-MCP; AFxRD-038) prepared over a 7-week period. After 1-MCP pretreatment, plants were exposed $2.5 \mu \mathrm{L} \cdot \mathrm{L}^{-1}$ ethylene or kept in an ethylene-free atmosphere for $18 \mathrm{~h}$ in darkness.

\begin{tabular}{lccc}
\hline $\begin{array}{l}1-\mathrm{MCP} \text { treatment } \\
\left(\mathrm{mg} \cdot \mathrm{L}^{-1}\right)\end{array}$ & $\begin{array}{c}\text { Ethylene treatment } \\
\left(\mu \mathrm{L} \cdot \mathrm{L}^{-1}\right)\end{array}$ & $\begin{array}{c}\text { Age of 1-MCP } \\
\text { solution }(\mathrm{wk})\end{array}$ & Flower abscission $(\%)$ \\
\hline 0 (control) & $0($ control $)$ & N/A & $12^{\mathrm{z}} \mathrm{c}$ \\
0 & 1 & $\mathrm{~N} / \mathrm{A}$ & $100 \mathrm{a}$ \\
10 & 1 & 0 & $13 \mathrm{c}$ \\
10 & 1 & 1 & $12 \mathrm{c}$ \\
10 & 1 & 2 & $13 \mathrm{c}$ \\
10 & 1 & 4 & $97 \mathrm{a}$ \\
10 & 1 & 5 & $70 \mathrm{~b}$ \\
10 & 1 & 7 & $100 \mathrm{a}$
\end{tabular}

${ }^{\mathrm{z}}$ Data are means of five replicates per treatment. Means followed by the same letter are not significantly different using Tukey-Kramer honestly significant difference at $P=0.05$.

concentrations involved are very similar to those needed for protection from ethylene.

Expt. 9: 1-MCP to prevent abscission in prolonged darkness. In the absence of ethylene, dark storage at $22{ }^{\circ} \mathrm{C}$ increased flower abscission in Impatiens $\times$ hawkeri 'Tamarinda Purple' and pretreatment with 10 $\mathrm{mg} \cdot \mathrm{L}^{-1}$ 1-MCP inhibited abscission (Table 7). When plants were kept in darkness for less than $3 \mathrm{~d}$, there was no difference in flower abscission with or without 1-MCP treatment. The effects of 1-MCP treatment, days in darkness and the $1-\mathrm{MCP} \times$ days in darkness interaction were all highly significant $(P<0.001)$ (Table 7$)$.

Shipping conditions are generally dark (not allowing for photosynthesis) and warm (increasing respiration rates). During shipping, carbohydrate levels decrease and plants may show symptoms of senescence such as lower leaf chlorosis, internode elongation, and abscission of buds and flowers (Jones, 2002). Holding Begonia $\times$ hiemalis plants in the dark caused more bud abscission than vibration or nonfreezing low temperature treatments and pretreatment with 1-MCP reduced abscission and increased display life (Kim et al., 2007). Skog et al. (2001) also showed that Impatiens $\times$ hawkeri 'Paradise Aglia' and I. walleriana 'Accent White' and 'Seashell' were improved with gaseous 1MCP pretreatment in the presence or absence of ethylene during postproduction. Impatiens $\times$ hawkeri, I. walleriana, and double Impatiens plants placed in cardboard boxes for 3 or $5 \mathrm{~d}$ showed significantly increased bud abscission, which was reduced by gaseous 1 MCP pretreatment (Han, 2003). From this, we suggest that Impatiens plants that will be subjected to postproduction stresses for more than $2 \mathrm{~d}$ may also be pretreated with sprayable 1-MCP.

Expt. 10: 1-MCP to prevent abscission at high temperatures. Impatiens hawkeri 'Tamarinda Purple' plants kept in darkness at $28{ }^{\circ} \mathrm{C}$ for $40 \mathrm{~h}$ exhibited significantly less flower abscission if treated with 1-MCP than untreated plants, regardless of the presence of exogenous ethylene (Table 8). The effects of $1-\mathrm{MCP}$, ethylene, and 1-MCP $\times$ ethylene were highly significant $(P<0.0001)$. Flower abscission damage to plants without a 1-MCP pretreatment was seen within $48 \mathrm{~h}$ in the absence of ethylene in warm temperatures $\left(28^{\circ} \mathrm{C}\right)$ (Table 8$)$, whereas damage was seen
Table 7. Flower abscission (\%) of Impatiens hawkeri 'Tamarinda Purple' sprayed with 1-methylcyclopropene (1-MCP; AFxRD-038). After treatment, plants were kept in darkness (ethylene-free atmosphere) for $1,2,3$, or $4 \mathrm{~d}$ at $22{ }^{\circ} \mathrm{C}$.

\begin{tabular}{lcc}
\hline $\begin{array}{l}\text { 1-MCP } \\
\text { pretreatment } \\
\left(\mathrm{mg} \cdot \mathrm{L}^{-1}\right)\end{array}$ & $\begin{array}{c}\text { Length of } \\
\text { darkness (d) }\end{array}$ & $\begin{array}{c}\text { Flower } \\
\text { abscission }(\%)\end{array}$ \\
\hline 0 & 1 & $0^{\mathrm{z}} \mathrm{b}$ \\
0 & 2 & $5 \mathrm{~b}$ \\
0 & 3 & $19 \mathrm{a}$ \\
0 & 4 & $34 \mathrm{a}$ \\
10 & 1 & $0 \mathrm{a}$ \\
10 & 2 & $1 \mathrm{a}$ \\
10 & 3 & $0 \mathrm{a}$ \\
10 & 4 & $3 \mathrm{a}$ \\
$1-$ MCP (M) & & $* * *$ \\
Darkness (D) & & $* * *$ \\
M $\times$ D & & $* * *$ \\
\hline
\end{tabular}

${ }^{\mathrm{z}}$ Data are means of five replicates per treatment. Means followed by the same letter are not significantly different using Tukey-Kramer honestly significant difference at $P=0.05$.

Significant at $P \leq 0.001$.

Table 8. Flower abscission (\%) of Impatiens hawkeri 'Tamarinda Purple' pretreated with 1-methylcyclopropene (1-MCP; AFxRD-038). After treatment, plants were exposed $1 \mu \mathrm{L} \cdot \mathrm{L}^{-1}$ ethylene or kept in an ethylene-free atmosphere in darkness for $40 \mathrm{~h}$ at $28^{\circ} \mathrm{C}$.

\begin{tabular}{lcc}
\hline $\begin{array}{l}\text { 1-MCP } \\
\text { pretreatment } \\
\left(\mathrm{mg} \cdot \mathrm{L}^{-1}\right)\end{array}$ & $\begin{array}{c}\text { Ethylene } \\
\text { treatment } \\
\left(\mu \mathrm{L} \cdot \mathrm{L}^{-1}\right)\end{array}$ & $\begin{array}{c}\text { Flower } \\
\text { abscission }(\%)\end{array}$ \\
\hline 0 & 0 & $6^{2} \mathrm{~b}$ \\
0 & 1 & $100 \mathrm{a}$ \\
10 & 0 & $0 \mathrm{~d}$ \\
10 & 1 & $2 \mathrm{c}$ \\
$1-\mathrm{MCP}(\mathrm{M})$ & & $* * *$ \\
Ethylene (E) & & $* * *$ \\
$\mathrm{M} \times \mathrm{E}$ & & $* *$ \\
\hline
\end{tabular}

${ }^{\mathrm{z}}$ Data are means of five replicates per treatment. Means followed by the same letter are not significantly different using Tukey-Kramer honestly significant difference at $P=0.05$.

Significant at $P \leq 0.001$.

in $3 \mathrm{~d}$ when plants were kept at cooler temperatures $\left(22^{\circ} \mathrm{C}\right)$ (Table 7$)$.

A survey of vegetatively propagated annual bedding plants by Starman et al. (2007) showed that under simulated shipping conditions (dark and warm, $26.7^{\circ} \mathrm{C}$ ) for 0,1 , or $2 \mathrm{~d}$, major symptoms of postproduction stress 
developed as lower leaf chlorosis $(81 \%$ of cultivars), internode elongation ( $38 \%$ of cultivars), flower senescence ( $38 \%$ of cultivars), and bud abortion (33\% of cultivars). Potted Rosa hybrida plants subjected to dark storage conditions for various lengths of time and a range of temperatures showed increased flower development (leading to senescence) with storage duration more than $2 \mathrm{~d}$ and the interaction of storage duration, temperature, and cultivar were significant with less development at $4{ }^{\circ} \mathrm{C}$ than $16{ }^{\circ} \mathrm{C}$ and greatest development at $28^{\circ} \mathrm{C}$ (Cushman et al., 1998).

\section{Conclusions}

The present work provides a basis for further experimentation with sprayable 1MCP on ornamental floriculture crops. Sprays of 1-MCP (AFxRD-038 formulation) at $10 \mathrm{mg} \cdot \mathrm{L}^{-1}\left(204 \mathrm{~mL} \cdot \mathrm{m}^{-2}\right)$ should be adequate to protect highly sensitive flowers from exposure to $1.0 \mu \mathrm{L} \cdot \mathrm{L}^{-1}$ exogenous ethylene for $18 \mathrm{~h}$ in darkness while lower concentrations will likely provide protection if applied at high volume (above $204 \mathrm{~mL} \cdot \mathrm{m}^{-2}$ ). Spray applications of 1-MCP were rainfast and fully efficacious within $1 \mathrm{~min}$ of application. The AFxRD-038 formulation was effective across a relatively wide $\mathrm{pH}$ range. As general practice, mixed solutions should be used soon after mixing but if held in an airtight container, solutions may show activity up to 2 weeks. Plants should be treated with 1-MCP within $3 \mathrm{~d}$ of potential postproduction ethylene exposure for full protection against stressors such as heat, darkness, and ethylene. AFxRD-038 shows great promise for future use in the floriculture industry to provide protection against postproduction stress and mediate ethylene damage in flowering plants.

\section{Literature Cited}

Armitage, A.M. 1993. Bedding plants: Prolonging shelf performance: Postproduction care and handling. Ball Publ. Co., Batavia, IL.

Blankenship, S.M. and J.M. Dole. 2003. 1-methylcyclopropene: A review. Postharvest Biol. Technol. 28:1-25.

Cameron, A.C. and M.S. Reid. 2001. 1-MCP blocks ethylene-induced petal abscission of Pelargonium peltatum but the effect is transient. Postharvest Biol. Technol. 22:169-177.

Choi, S.T., P. Tsouvaltzis, C.I. Lim, and D.J. Huber. 2008. Suppression of ripening and induction of asynchronous ripening in tomato and avocado fruits subjected to complete or partial exposure to aqueous solutions of 1-methylcyclopropene. Postharvest Biol. Technol. 48:206-214.

Cushman, L.C., H.B. Pemberton, J.C. Miller, and J.W. Kelly. 1998. Interactions of flower stage, cultivar, and shipping temperature and duration affect pot rose performance. HortScience 33:736-740.

Dostal, D.L., N.H. Agnew, R.J. Gladon, and J.L. Weigle. 1991. Ethylene, simulated shipping, STS, and AOA affect corolla abscission of new guinea impatiens. HortScience 26:47-49.

Environmental Protection Agency (EPA). 2016. US Label AFxRD-038. 18 July 2016. <http://www. kellysolutions.com/ne/showproductinfo.asp?Product_ Name=AFXRD-038\&EPA_Id=71297-6>.

Gibson, J.L., B.E. Whipker, S. Blankenship, M. Boyette, T. Creswell, and J. Miles. 2000 Ethylene: Sources, symptoms, and prevention for greenhouse crops. North Carolina State University College of Agriculture \& Life Science, Dept. of Horticultural Science, Horticulture Information Leaflet, 530.

Han, S.S. 2003. Preventing premature bud drop: Evaluation of 1-MCP for prevention of premature bud drop in Impatiens walleriana, double impatiens, and New Guinea impatiens. Greenhouse Product News. December, 58-61.

Healy, W. 2009. Piles of money. GrowerTalks Mag. 72:42-46.
Jones, M.L. 2002. Postproduction care and handling. Ohio Flor. Assn. Bul. 872:15-16.

Jones, M.L. and N. Edelman. 2013. Avoiding damage. 13 Oct. 2016. <http://www.greenhousemag. com/gm0113-prevent-ethylene-damage-crops. aspx $>$.

Latimer, J. and B. Whipker. 2012. Selecting and using plant growth regulators on floricultural crops. 18 July 2016 . <https://vtechworks.lib.vt. edu/handle/10919/48109>.

Kim, Y.J., S. Kwon, and K.S. Kim. 2007. 1-MCP improves postharvest quality of Begonia $\times$ hiemalis. Acta Hort. 755:437-444.

MacKinnon, D.K., D. Shaner, S. Nissen, and P. Westra. 2009. The effects of surfactants, nozzle types, spray volumes, and simulated rain on 1 -methylcyclopropene efficacy on tomato plants. HortScience 44:1600-1603.

Manganaris, G.A., A.R. Vicente, C.H. Crisosto, and J.M. Labavitch. 2007. Effect of dips in a 1-methylcyclopropene-generating solution on 'Harrow sun' plums stored under different temperature regimes. J. Agr. Food Chem. 55:7015-7020.

Reid, M.S. and F.G. Çelikel. 2008. Use of 1methylcyclopropene in ornamentals: Carnations as a model system for understanding mode of action. HortScience 43:95-98.

Reid, M.S. and C.-Z. Jiang. 2012. Postharvest biology and technology of cut flowers and potted plants. Hort. Rev. 40:1-54.

Skog, L.J., T. Blom, B. Schaefer, B. Digweed, H. Fraser, and W. Brown. 2001. A survey of ethylene contamination in Ontario's floriculture industry and the evaluation of 1-methylcyclopropene and an ethylene absorber as potential solutions. Acta Hort. 543:55-62.

Staby, G.L., J.L. Robertson, D.C. Kiplinger, and C.A. Conover. 1978. Chain of life. 18 July 2016. <http://hdl.handle.net/1811/56166>.

Starman, T.W., S.E. Beach, and K.L. Eixmann. 2007. Postharvest decline symptoms after simulated shipping and during shelf life of 21 cultivars of vegetative annuals. HortTechnology 17:544-551. 